and it was well understood that the protection of Arabis stricta was the motive, or a chief motive, of the authorities.

Higher Shute Cottage, Polperro, Cornwall, September 29.

Mr. Perrycoste is quite right in suggesting that the special flora of Cheddar might be destroyed in such a way as to bring the offender under the by-law in question, but this does not interfere with my statement that the flora might be destroyed without any contravention of the by-law; it is much more probable that the flora will be gradually extinguished than by a single act of vandalism.

EDW. FRY.

IN addition to the existence of a local order for the protection of wild flowers in Cornwall, extending only to the highways, there are other counties, such as Essex, Surrey, Sussex, and Devon, that have already availed themselves of the power to frame a by-law applying to a separate county.

Though these means of restricting hawking and excessive collecting exist on a limited scale at present, it is the aim of the Plant Protection Section of the Selborne Society to obtain the cooperation of all county councils in the framing of by-laws throughout the country. This, indeed, it must be stated, is apparently the only course left, for the experience of county councils in applying singly for this power to the Home Office has been distinctly discouraging. In fact, the Home Office has refused to increase the number of local orders; so that the only method to adopt is to get every county council to apply simultaneously, when the force of public opinion thus expressed will not fail, we hope, to have the desired effect.

Of course, the securing of a local order for Somerset, as advocated by Sir Edward Fry, would not be equivalent to the establishment of a flower-sanctuary. Unless land were purchased by the National Trust, or some kindred public-spirited body, or by private enterprise, the making of a reservation of anv tract without the owner's consent is out of the power of the Government. At least, we have not come to land nationalisation as yet (save the mark!).

The desirability of the formation of wild-flower reservations is undeniable. It is one of the projects kept in view by the Plant Protection Section. One of the methods of securing this end will be the obtaining of the support of the scientific societies of the country, and the appointment of a corresponding secretary in each district to advise upon what tracts require reservation and what facilities exist locally for their formation. The writer's investigation into the voluminous causes of extermination of plants has shown that there are numerous localities in every county of the British Isles which require reservation or protection. It is obvious that no one body such as the Selborne Society could undertake to carry on single-handed the enormous amount of organisation required to protect actively plants locally without effective assistance from such bodies, or without some organised effort. This question is on the tapis at the next meeting of the section, which I hope Sir Edward Fry will attend, and it is hoped to prosecute this part of the campaign very actively during the coming winter. The assistance of any who can render service in this matter of enlisting the sympathies of the scientific societies will be very gratefully received. The result of an appeal to the county councils last year to aid in the creating of a public protest against exterminating wild flowers, especially addressed to the schools, in which the collecting necessary to the pursuit of nature-study was involved, was very encouraging.

The whole question resolves itself, in fine, to the obtaining of State protection of wild plants (and animals) in this country, as in Prussia. This is the prime object the section has in view. In the meantime, it is endeavouring to create a public opinion in favour of the movement, until such time as the occasion is ripe for making a concerted appeal for Government control.

A. R. HoRwOOD,

Recorder, Plant Protection Section of the Selborne Society.

Leicester Museum, September 27.

\section{The Summer of 1912.}

IN Nature of September 19, Mr. Harding concludes a very interesting article on the recent summer in the British Islands, by recording the fact that "the temperature of the sea-surface in the North Atlantic and in proximity to our own coasts has for some time past been much below the average." This seems to bear out what I have been telling people for weeks past-that the abnormal chilliness of the past summer, and especially of the month of August, was in all probability due to the cooling of the Gulf Stream by the abnormal ice-drift on the other side of the Atlantic, to which the disastrous fate of the Titanic forced the tardy attention of even the great shipping companies. A reference to such a thorough-going atlas as that of Diercke and Gaebler (p. 2I) will show what this must mean, when not only icebergs but extensive icefloes in such numbers were melting away in the latitudes of the Spanish peninsula, and even further south than the latitude of Gibraltar, in the very path of the Gulf Stream Drift, and even of the return North Equatorial current, with the natural result that these islands, within the same latitudes as Labrador, should have a taste of something like a Labrador summer.

If we make a little scientific use of the imagination, asking ourselves what would be the climatic results to north-western Europe of the obliteration of the Gulf Stream altogether, we may arrive at some inferential results as to the importance of such a causal factor among the conditions which existed in the Pleistocene period of glaciation, when-as Prof. J. W. Spencer (Bull. Geol. Soc. America, vol. vi.) has shown -the elevation of the Antillean Continent was such that we may infer the impossibility of the existence of the Gulf Stream as such for the greater part of that period.

That would leave us no more than such a mere wind-drift of surface ocean-water as is seen in the "Kuro-Siwo" of the North Pacific at the present time (op. cit., p. 13). See further, Tarr, "Physical Geography" (pp. 182-19I) and "The International Geography" (p. 69), both published by Messrs. Macmillan and $\dot{C}$.

A. IRVING.

Hockerill, Bishop's Stortford, September 30.

\section{Turkish Earthquake of September 13.}

The bulletin from Pulkowa has just reached me, and from this it appears that the azimuth of the epicentre from Pulkowa was $9^{\circ} 12^{\prime}$ west of south. Two estimates of the distance are given, leading respectively to $4 \mathrm{r}^{\circ} \mathrm{I}^{\circ} \mathrm{N}, 2^{\circ}{ }_{4} \mathrm{E}$., and $40^{\circ} \mathrm{I}^{\circ} \mathrm{N} ., 26^{\circ} 3^{\circ} \mathrm{E}$. The epicentre determined here was $40^{\circ} 4^{\circ} \mathrm{N}$., $269^{\circ} \mathrm{E}$., and the azimuth was $65^{\circ} 33^{\prime}$ east of south.

From the two azimuths alone I find the epicentre to be $40^{\circ} 7^{\circ} \mathrm{N} ., 26^{\circ} 5^{\circ} \mathrm{E}$. GeORGE W. WALKER.

The Observatory, Eskdalemuir, Langholm, Dumfriesshire, October r. NO. 224I, vol. 90] 